\title{
PEMANFAATAN BONGGOL JAGUNG SEBAGAI BAHAN ABSORBEN PADA LIMBAH PEWARNA BATIK DI DESA BANYUBIRU
}

\author{
Dedy Richi Rizaldy ${ }^{1,}$ Rida Fahas ${ }^{2}$, Puput Jianggimahastu ${ }^{3}$ \\ Universitas PGRI Madiun ij email: dedy.rr@unipma.ac.id \\ Universitas PGRI Madiuni email: rida.fahas@unipma.ac.id \\ Universitas PGRI Madiun3; email: puput.jiang@unipma.ac.id
}

\begin{abstract}
Abstrak
Kegiatan pengabdian kepada masyarakat ini dilakukan untuk memberikan penyuluhan, pembinaan dan pelatihan kepada masyrakat pengerajin batik di Desa Banyu Biru, Kecamatan Widodaren, Kabupaten Ngawi.hal ini dilakukan karena para pengrajin batik tersebut menggunakan pewarna sintetis dalam mewarnai produk mereka dan membuang limbah pewarna secara sembarangan. Hal ini tentunya akan berpengaruh kepada lingkungan mereka. Oleh karena itu perlu adanya penyuluhan, pembinaan dan pelatihan dalam rangka mengurangi pembuangan limbah secara sembarangan tersebut.
\end{abstract}

Kata Kunci: Bonggol Jagung, Absorben, Limbah, Batik

\section{Abstract}

This community service activity is carried out to provide counseling, guidance and training to the community of batik craftsmen in Banyu Biru Village, Widodaren District, Ngawi Regency. This is done because the batik craftsmen use synthetic dyes in coloring their products and dispose of dye waste carelessly. This of course will affect their environment. Therefore, there is a need for counseling, coaching and training in order to reduce the indiscriminate disposal of waste.

Keywords: Corn Cob, Absorbent, Waste, Batik

\section{PENDAHULUAN}

Pengolahan sampah (limbah) di Indonesia masih menjadi satu persoalan yang hingga kini masih perlu untuk ditingkatkan penangananya baik itu limbah organik maupun non organik. Jumlah limbah diperkirakan semakin meningkat dari tahun ketahun. Kementerian Lingkungan Hidup dan Kehutanan terus melakukan penelitian mengenai persoalan ini dan menemukan data yang menunjukan bahwa sampah jenis non organik terus meningkat diantara jenisnya adalah sampah plastik, limbah kimia, limbah B3, dll. (CNN Indonesia, 2019)

Salah satu jenis limbah non organik adalah limbah B3 yang merupakan limbah buangan yang kebanyakan berbentuk cair dan diketahui berpotensi untuk mengancam lingkungan serta kesehatan manusia. Limbah $\mathrm{B}_{3}$ yang merupakan akronim dari bahan beracun dan berbahaya yang sifat konsentrasinya mengandung zat beracun dan berbahaya sehingga dapat mengganggu kelangsungan hidup manusia maupun organisme lainya. Limbah tersebut seringkali ditemukan dari sisa-sisa bahan kimia cair seperti limbah industri, limbah pewarna tekstil, limbah pewarna batik, dll. 
Limbah organik diketahui tidak memiliki ancaman untuk lingkungan dan dapat memberikan manfaat lebih jika dapat dilakukan pengolahan limbah secara tepat. Limbah yang berasal dari sisa-sisa sumber organik ini sifatnya dapat dikembalikan ketanah untuk dapat diuraikan oleh mikroorganisme yang dapat meningkatkan kesuburan tanah. Sebagai contoh adalah limbah hasil pertanian seperti jerami padi, sekam, brangkasan kacang-kacangan, bonggol jagung, kotoran ternak, dll. Limbah organik dapat dimanfaatkan sebagai media untuk mengurangi dampak buruk yang ditimbulkan oleh limbah non organik dengan melalui cara kreatif dan inovatif dalam pengolahanya.

Desa Banyubiru (Widodaren, Ngawi) adalah desa seni yang menghasilkan kerajinan kain batik yang telah diwariskan turun temurun dari beberapa generasi yang hingga sekarang masih bertahan. Namun, pengolahan limbah yang ditimbulkan dari pewarna tekstil yang digunakan dalam membuat kerajinan batik belum memiliki cara pengolahan yang cukup tepat sehingga dikhawatirkan akan adanya dampak buruk bagi lingkungan. Limbah yang dihasilkan hanya disiram begitu saja ke tanah maupun selokan sekitar area pengolahan batik. Hal ini dilakukan oleh hampir seluruh pelaku usaha kerajinan batik dari beberapa rumah pengrajin batik di desa Banyubiru. Hal ini yang dapat menimbulkan kekhawatiran akan kerusakan lingkungan yang dapat ditimbulkan dari kelalaian dalam pembuangan limbah pewarnaan batik tersebut.

Komoditas utama yang dihasilkan oleh masyarakat Desa Banyubiru adalah Jagung \& Padi. Jagung memiliki limbah organik berupa bonggol jagung maupun kulit jagung yang bisa dimanfaatkan sebagai media yang dapat membantu pengolahan limbah pewarna tekstil yang digunakan untuk membuat batik. Bonggol jagung dapat digunakan sebagai absorben limbah cair yang dihasilkan dari proses pewarnaan batik sehingga limbah yang dihasilkan tersebut tidak hanya dibuang begitu saja. Untuk mengatasi masalah terkait pembuangan limbah cair dari zat pewarna batik, solusi yang dapat ditawarkan adalah dengan melakukan pelatihan bagi masyarakat desa Banyubiru dalam memanfaatkan bonggol jagung sebagai media absorben dalam pengolahan limbah pewarna batik.

\section{METODE}

Metode yang digunakan dalam kegiatan ini adalah melakukan penyuluhan sekaligus pendampingan dengan tujuan membekali pengetahuan dasar pada anggota koperasi batik Sidomukti tentang bahaya limbah pewarna batik yang belum diolah sebagaimana mestinya, kemudian diberikan pelatihan dasar tentang bagaimana cara mengolah limbah yang benar sehingga tidak menimbulkan dampak kerusakan terhadap lingkungan. Selanjutnya para anggota koperasi batik Sidomukti akan diberikan sekilas materi dan pelatihan tentang bahaya yang ditimbulkan jika langsung membuang limbah bekas pewarna batik tanpa diolah terlebih dahulu serta bagaimana cara mengatasinya. Selain itu, yang lebih penting lagi adalah mengubah sikap dan perilaku masyarakat pengrajin batik agar mereka tahu dan mau menerapkan informasi atau anjuran yang disampaikan oleh Penyuluh. 
Dengan menggunakan bahan bonggol jagung, masyarakat diberi pemahaman tentang pengolahan limbah pewarna batik melalui proses absorpsi. Selanjutnya setelah dilakukan pelatihan akan dilakukan pemantauan apakah kegiatan tersebut masih dilakukan atau tidak, jika dilakukan maka kegiatan dimaksud otomatis bermanfaat atau berdampak baik terhadap petani, tetapi jika tidak, maka akan ditanyakan kendalanya.

\section{HASIL DAN PEMBAHASAN}

Kegiatan dilaksanakan dengan melalui beberapa tahapan. Yang pertama yaitu observasi awal masyarakat sasaran dan memberikan gambaran tentang kegiatan yang akan dilakukan. Selanjutnya adalah pengamatan terhadap beberapa limbah yang dihasilkan oleh masyarakat pengrajin batik dan bagaimana mereka memproses limbah tersebut. Berdasarkan hasil pengamatan, limbah yang dihasilkan dari pewarnaan tidak diolah dengan benar melainkan langsung di buang begitu saja ke tanah ataupun aliran sungai. Melalui program penyuluhan, kegiatan ini diawali dengan membekali pengetahuan dasar pada anggota koperasi batik Sidomukti tentang bahaya limbah pewarna batik yang belum diolah sebagaimana mestinya, kemudian diberikan pelatihan dasar tentang bagaimana cara mengolah limbah yang benar sehingga tidak menimbulkan dampak kerusakan terhadap lingkungan. Kegiatan selanjutnya adalah dengan memberikan pelatihan pengolahan limbah pewarna batik dengan menggunakan media bonggol jagung sebagai bahan absorben.

Dalam kegiatan ini juga memfasilitasi bahan utama absorben yaitu bonggol jagung, yang diberikan kepada tiap pengrajin. Dari hasil kegiatan pengabdian masyarakat yang dilakukan, 35 pengrajin telah menerima bonggol jagung yang dapat secara lanngsung digunakan sebagai metode pengolahan limbah sesuai dengan penyuluhan yang diberikan. Kegiatan penyuluhan dan praktek pengolahan limbah yang dilakukan memberika hasil bahwa masyarakat dapat mengubah perilaku pengrajin batik yang membuang limbah secara langsung ke lingkungan sekitar secara langsung menjadi mengolah limbah tersebut terlebih dahulu.

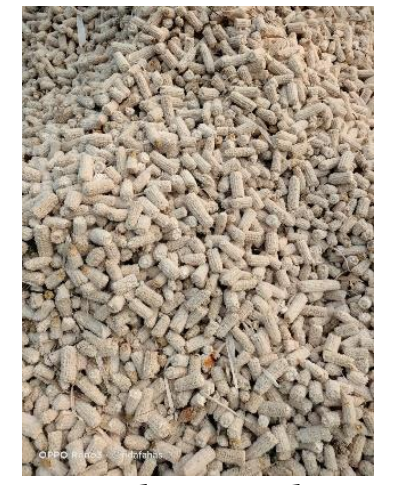

gambar 1. Bonggl jagung kering sebagai bahan absorben

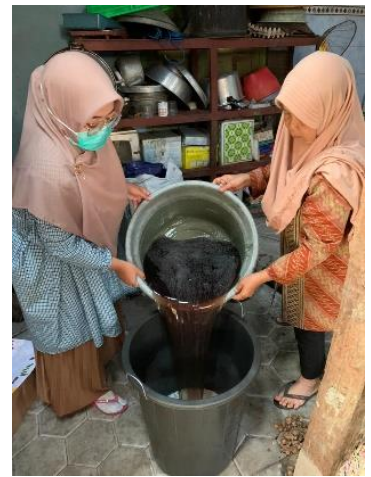

gambar 2. Pengumpulan limbah pewarna batik 


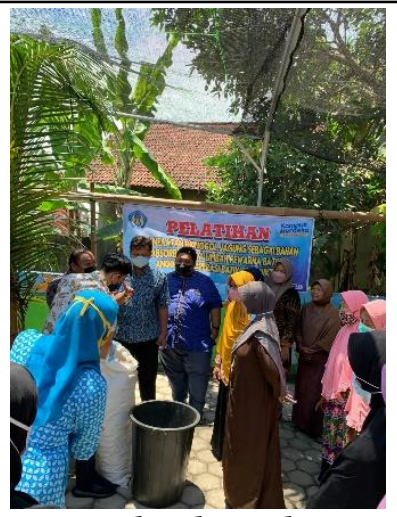

gambar 3. Pelatihan dan praktek

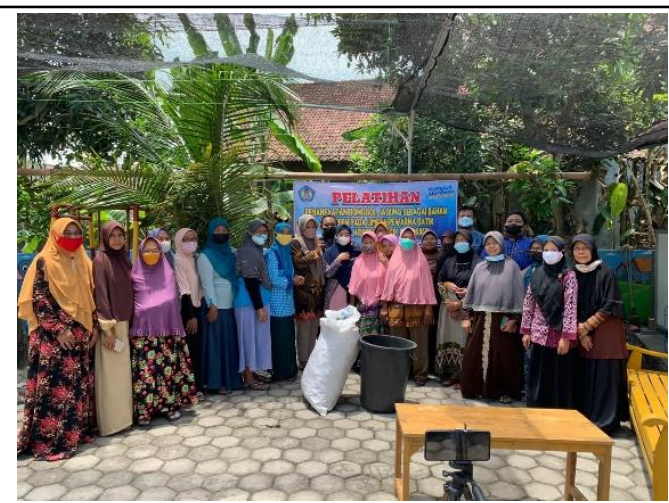

gambar 4. Kelompok pengrajin batik Sidomukti

\section{KESIMPULAN}

Kesimpulan dari kegiatan pemberdayaan masyarakat dalam hal pemanfaatn bonggol jagung sebagai bahan absorben pada limbah pewarna batik yaitu masyarakat desa Banyubiru mulai menyadari betapa berbahanya dampak yang ditimbulkan dari limbah hasil pewarnaan batik, Pengabdian ini merupakan tahapan awal dari serangkaian proses pengolahan limbah pewarna batik dengan memanfaatan bonggol jagung sebagai absorben limbah cair yang dihasilkan dari proses pewarnaan batik sehingga menghasilkan limbah yang lebih ramah terhadap lingkungan, yang nantinya tidak menimbulkan kerusakan lingkungan sekitar.

Untuk keberlanjutannya, hasil dari penelitian ini dapat dikembangkan untuk mengetahui hasil yang lebih akurat tentang mekanisme dan gugus fugsi yang berperan dalam proses adsorpsi serta metode manakah yang lebih efektif untuk digunakan sebagai proses adsorpsi.

\section{REFERENSI}

Alfiany, H., B. Syaiful, dan Nurakhirawan. 2013. Kajian Penggunaan Arang Aktif Tongkol Jagung Sebagai Absorben Logam $\mathrm{Pb}$ dengan Beberapa Aktivator Asam. Jurnal Natural Science, 2 (3): 75-86.

Ahmad, R. 2009, Study In Adsorpsions Of Crystal Viole Dan From Aqueos Solations Onto Ciniferou Pinus Bark Powder (CPNP), J Hajard mater.

Bharathi, K. S. and S. T. Ramesh. 2013. Removal of dyes using agricultural waste as lowcost adsorbents: a review. Journal of Applied Water Science. pp. 773- 790.

Budiono, A, Suhartana, Gunawan. 2010. Pengaruh Aktivasi Arang Tempurung Kelapa Asam Sulfat dan Fosfat untuk Adsorpsi Fenol. Laboratorium Kimia Anorganik, Laboratoium Kimia Nalitik.Jursan Kimia .Universitas Indonesia Diponogoro

Patel, R. dan S. Surest. 2008. Kinetic And Equlilelibrium Studies On The Biosorption Of Reactive Black 5 Dye By Asperqillus Foutidus.Bioresour Tehnology.Pp.51-5

Pambayun, G. S., Y. E. Y. Remigius, M. Rachimoellah, dan M. M. P. Endah. 2013. Pembuatan Karbon Aktif dari Arang Tempurung Kelapa dengan Aktivator 
$\mathrm{ZnCl}_{2}$ Dan $\mathrm{Na}_{2} \mathrm{CO}_{3}$ Sebagai Adsorben Untuk Mengurangi Kadar Fenol Dalam Air Limbah. Jurnal Teknik Pomits. Vol. 2, No. 1

Patel, R. and S. Suresh. 2008. Kinetic and equilibrium studies on the biosorption of reactive black 5 dye by Aspergillus foetidus. Bioresour Technology. pp.51-58.

Purwanto, D. 2011. Arang dari Limbah Kelapa Sawit (Elaeis guineensis Jacq). Badan Penelitian dan Pengembangan Kehutanan. Bogor. Jurnal Penelitian Hasil Hutan. Vol. 29, No.

Ruslan, K. W. (2013). Study of physico-chemical properties of Si [O. sub. 2]-[Al. sub. 2][O. sub. 3]/bentonite nanocomposite: thermal and acid stability. International Journal of Applied Chemistry, 9(1), 15-36.

Sallau, B., A. Aliyu, Salihu and S. Ukuwa. 2012. Biosorption of Chromium (VI) from Aqueous Solution by Corn Cob Powder. International Journal of Environmrnt and Bioenergy, 4(3): 131-140

Sudarja dan N, Caroko. 2012. Kaji Eksperimental Efektifitas Penyerapan Limbah Cair Industri Batik Taman Sari Yogyakarta Menggunakan Arang Aktif Mesh 8o dari Limbah Gergaji Kayu Jati. Jurnal Ilmiah Semesta Teknika. Vol. 14, hal. 50-58

Surest, A.H. 2008. Pengaruh Suhu, Konsentrasi Zat Aktivator dan Waktu Aktivasi terhadap Daya Serap Karbon Aktif dari Tempurung Kemiri. Jurnal Teknik Kimia.2(15)

Suhartati, T. 2017. Dasar-Dasar Spektrofotometri UV-Vis dan Spektrometri Massa untuk Penentuan Struktur Senyawa Organik. Lampung: Anugrah Utama Raharja. 